\title{
Total Synthesis of Piericidin A1 and B1 and Key Analogues
}

\author{
Martin J. Schnermann ${ }^{a}$, F. Anthony Romero ${ }^{a}$, Inkyu Hwanga ${ }^{a}$, Eiko Nakamaru-Ogisob, Takao \\ Yagi ${ }^{\mathrm{b}}$, and Dale L. Bogera \\ aDepartment of Chemistry and the Skaggs Institute for Chemical Biology The Scripps Research Institute, \\ 10550 North Torrey Pines Road, La Jolla, California 92037
}

bDepartments of Molecular and Experimental Medicine, The Scripps Research Institute, 10550 North Torrey Pines Road, La Jolla, California 92037

\begin{abstract}
Full details of the total synthesis of piericidin $\mathrm{A} 1$ and $\mathrm{B} 1$ and its extension to the preparation of a series of key analogues are described including ent-piericidin A1 (ent-1), 4'-deshydroxypiericidin A1 (58), 5'-desmethylpiericidin A1 (73), 4'-deshydroxy-5'-desmethylpiericidin A1 (75), and the corresponding analogues $\mathbf{5 1}, \mathbf{5 9}, \mathbf{7 6}$, and $\mathbf{7 7}$ bearing a simplified farnesyl side chain. The evaluation of these key analogues, along with those derived from their further functionalizations, permitted a scan of the key structural features providing new insights into the role of the substituents found in both the pyridyl core as well as the side chain. A strategic late stage heterobenzylic Stille crosscoupling reaction of the pyridyl core with the fully elaborated side chain permitted ready access to the analogues in which each half of the molecule could be systematically and divergently modified. The pyridyl cores were assembled enlisting inverse electron demand Diels-Alder reactions of $\mathrm{N}$ sulfonyl-1-azabutadienes while key elements of side chain syntheses include an anti selective asymmetric aldol to install the $\mathrm{C} 9$ and $\mathrm{C} 10$ relative and absolute stereochemistry (for natural and ent-1) and a modified Julia olefination for formation of the C5-C6 trans double bond with convergent assemblage of the side chains.
\end{abstract}

\section{Introduction}

Piericidin A1 (1) is the prototypical member of an important class of biologically active natural products isolated from Streptomyces mobaraensis and pactam (Figure 1). ${ }^{1}$ The most widely recognized biological target of $\mathbf{1}$ and members of this natural product class is the mitochondrial electron transport chain protein NADH-ubiquinone reductase (Complex I) and the piericidins are among the most potent inhibitors identified to date $\left(K_{\mathrm{i}}=0.6-1.0 \mathrm{nM}\right)$. Complex I mediates the transfer of protons into the intermembrane space of the mitochondria through a NADH driven reduction of ubiquinone $(3)$ to its hydroquinone $e^{2}$ and the piericidins have contributed extensively to the elucidation of the properties of this highly complex enzyme. ${ }^{3}$ Although initially investigated as an insecticide, the piericidins have been found to exhibit a range of promising biological activity. Some piericidins have been shown to exhibit antimicrobial and antifungal activity with minimum inhibitory concentrations as low as $6 \mu \mathrm{g} / \mathrm{mL}$, while others have been shown to block antibody formation (inhibit the immune response to antigen exposure) at the remarkably low concentrations of $100 \mathrm{pg} / \mathrm{mL} .{ }^{4-6}$ Most recently, $\mathbf{1}$ was identified as a potent inhibitor of interleukin-2 (IL-2) production in a cellular functional assay.

${ }^{7} \mathrm{IL}-2$ is a regulator of many essential immune responses and its over-expression is linked to

E-mail: boger@scripps.edu.

Supporting Information Available. Full experimental details are provided in the supporting information. This material is available free of charge via the Internet at http://pubs.acs.org. 
malignancy, autoimmune diseases, organ transplant rejection, and renal allograft rejection. Additionally, and of the most significance to our own interests, $\mathbf{1}$ was identified as a highly selective antitumor agent with greater selectivity and potency than the comparison standard mitomycin C. ${ }^{8}$ In fact, a number of Complex I inhibitors from the rotenoid class of natural products, of which rotenone (4) is the prototypical member, have received considerable attention as anti-cancer agents and have exhibited efficacious in vivo activity in animal models. ${ }^{9}$ Although the precise mechanism responsible for the selective antitumor activity of such Complex I inhibitors has not been fully elucidated, several explanations have been advanced. 10-13

Despite this array of potentially useful biological activity, no total synthesis of a member of this large class of natural products had been described prior to our initial disclosure. ${ }^{14}$ Shortly following this preliminary disclosure, Phillips and Keaton reported a complementary total synthesis of (-)-7-demethylpiericidin A1, a natural product closely related to $1 .^{15}$ In earlier efforts directed at this family, a racemic synthesis of analogues incorporating the full side chain, but a substituted benzene in place of the substituted pyridine of $\mathbf{1}$ has been disclosed, and an asymmetric synthesis of the $\mathrm{C} 6-\mathrm{C} 13$ segment of the side chain bearing the most recent stereochemical assignment $(9 R, 10 R)$ has been reported. ${ }^{16,17}$ In addition, the preparation of several analogues bearing simplified side chains have been disclosed. ${ }^{18-20}$ Notably, and at the time that our work and that of Phillips was conducted, the originally assigned absolute stereochemistry ${ }^{21}$ of the side chain substituents of 1 had been challenged, reassigned, and remained to be unambiguously established. 22,23

Herein we provide full details of this synthesis of piericidin A1 and B1 by an approach that, like that of Phillips, established the absolute stereochemistry of the natural products and report its subsequent extension to the synthesis and evaluation of a series of key analogues (Figure 2). Central to the approach is the use of an inverse electron demand Diels-Alder reaction of a $N$-sulfonyl-1-aza-1,3-butadiene ${ }^{24}$ with tetramethoxyethene ${ }^{25}$ followed by Lewis acidpromoted aromatization for assemblage of the functionalized pyridine core. ${ }^{26}$ Based on prior work with such systems, an azadiene bearing an additional strong electron-withdrawing group at C-2 would be expected to facilitate the Diels-Alder reaction such that the fully substituted and sensitive tetramethoxyethene could be anticipated to react under mild conditions.

Additional key elements of the approach include the use of an asymmetric anti-aldol reaction to install the $\mathrm{C} 9$ and $\mathrm{C} 10$ relative and absolute stereochemistry, a modified Julia olefination for formation of the C5-C6 trans double bond with convergent assemblage of the side chain, and a surprisingly effective penultimate heterobenzylic Stille cross-coupling reaction of the pyridyl core with the fully elaborated side chain. Notably, the strategic late stage coupling of the fully functionalized pyridyl core with the fully elaborated side chain was anticipated to permit access to analogues in which either half of the molecule could be systematically and divergently 27 altered.

Thus, in addition to the natural products, we were especially interested in the synthesis of a series of analogues that would define the key features of this class of molecules responsible for their biological activity. Of particular interest was the suggestion that the 4-hydroxypyridine of $\mathbf{1}$, as the pyridone tautomer, mimics the quinone of ubquinone (coenzyme $\mathrm{Q}, \mathbf{3}$ ) with the side chain of $\mathbf{1}$ mimicking the prenyl chain. This apparent structural relationship has been confirmed through their competitive binding against Complex I. However, competitive substrate binding may not fully account for the inhibitory activity as $\mathbf{1}$ binds to at least two sites on Complex I; one competitive with coenzyme $Q$ and one competitive with rotenone, neither of which are competitive with each other. ${ }^{3,28,29}$ Moreover and although piericidin A1 competitively blocks the binding of endogenous ubiquinone (the most upstream inhibition site of the inhibitor-binding domain of Complex I), the majority of specific Complex I inhibitors exhibit noncompetitive or uncompetitive behavior against the artificial substrate n- 
decylubiquinone. ${ }^{30}$ Thus, the absence of mutual exclusivity between the inhibitor and the ubiquinone binding sites presents a major challenge in identifying the actual Complex I sites of action of these potent agents and their relation to the ubquinone reduction sites. ${ }^{31}$ Thus, the exact role of the apparent structural homology between $\mathbf{1}$ and $\mathbf{3}$ has not been fully established. It was envisioned that a carefully constructed series of analogues could be used to probe such questions.

\section{Total Synthesis of Piericidin A1 and Piericidin B1}

Our initial objective was to use the Diels-Alder reaction of tetramethoxyethene with $\mathrm{N}$ sulfonyl-1-azadiene $6^{32}$ bearing a $C 4$ benzyloxy substituent permitting direct access to the fully substituted pyridine upon base-catalyzed aromatization (Scheme 1). Conversion of the ketone 5 to the requisite azadiene $6\left(\mathrm{PhSO}_{2} \mathrm{NH}_{2}, \mathrm{TiCl}_{4}, 0{ }^{\circ} \mathrm{C}, 1 \mathrm{~h}, 20 \%\right)$ proved problematic providing 6 in low yields. Similarly, the alternative two-step approach enlisting the oxime 7 did not prove viable. More significantly, $N$-sulfonyl-1-azadiene $\mathbf{6}$ failed to react with either $8^{25}$ or ethyl vinyl ether in an initial survey of reaction conditions.

Based on this initial finding, it was decided that the C4' hydroxyl could be installed following the Diels-Alder and aromatization sequence permitting the use of the less substituted and more electron-deficient $N$-sulfonyl-1-azadiene 12 (Scheme 2). This key $N$-sulfonyl-1-aza-1,3butadiene was accessed through a two-step sequence initiated by oxime formation of the ketone $\mathbf{1 0}^{33}\left(\mathrm{NH}_{2} \mathrm{OH}-\mathrm{HCl}, \mathrm{EtOH}, 25^{\circ} \mathrm{C}, 18 \mathrm{~h}, 96 \%\right)$. Treatment of the oxime 11 with $\mathrm{Et}_{3} \mathrm{~N}$ and methylsulfinyl chloride led to initial formation of the $O$-methanesulfinate and its in situ homolytic rearrangement to give sulfonylimine $12\left(\mathrm{CH}_{3} \mathrm{SOCl}, \mathrm{Et}_{3} \mathrm{~N}, \mathrm{CH}_{2} \mathrm{Cl}_{2}, 0{ }^{\circ} \mathrm{C}, 20 \mathrm{~min}\right)$. 34 Direct conversion of the ketone 10 to $12\left(\mathrm{MeSO}_{2} \mathrm{NH}_{2}, \mathrm{TiCl}_{4}, 0{ }^{\circ} \mathrm{C}, 1 \mathrm{~h}, 40 \%\right)$ was also possible, but was not pursued due to lower initial conversions. Treatment of $\mathbf{1 2}$ with $\mathbf{8}$ (toluene, $50{ }^{\circ} \mathrm{C}, 18 \mathrm{~h}, 64 \%$ for 2 steps from 11 ) smoothly afforded the [4+2] cycloadduct $\mathbf{1 3}$. As anticipated, the electron-deficient $N$-sulfonyl-1-azadiene 12 substituted with the additional $\mathrm{C} 2$ electron-withdrawing substituent ${ }^{26 a, b}$ participated in the Diels-Alder reaction with the electron-rich dienophile $\mathbf{8}$ at or near room temperature even though $\mathbf{8}$ is tetrasubstituted and sterically demanding. Despite its potential hydrolytic lability, the cycloadduct 13 (mp 116$118^{\circ} \mathrm{C}$ ) proved remarkably robust being isolated by conventional chromatography on $\mathrm{SiO}_{2}$ and its structure was confirmed by single crystal Xray diffraction (Figure 3). ${ }^{35}$ Although efforts to induce aromatization of $\mathbf{1 3}$ under a variety of basic conditions were surprisingly unsuccessful, having been anticipated to result from a well-precedented $\mathrm{C} 4$ deprotonation and elimination of a $\mathrm{C} 3$ methoxy group followed by methanesulfonyl deprotonation and loss of sulfene concurrent with $\mathrm{C} 2$ methoxy elimination, ${ }^{36}$ the use of the Lewis acid $\mathrm{BF}_{3} \cdot \mathrm{OEt}_{2}$ cleanly affected this transformation $\left(\mathrm{CH}_{2} \mathrm{Cl}_{2}, 0{ }^{\circ} \mathrm{C}, 1 \mathrm{~h}, 88 \%\right)$. Reduction of the ethyl ester 14 with DIBALH $\left(\mathrm{CH}_{2} \mathrm{Cl}_{2}, 0{ }^{\circ} \mathrm{C}, 1 \mathrm{~h}, 92 \%\right)$ followed by protection of the resulting alcohol $\mathbf{1 5}$ as its TIPS ether provided 16 (TIPSCl, imidazole, DMF, $25^{\circ} \mathrm{C}, 18 \mathrm{~h}, 95 \%$ ). We had envisioned that directed lithiation of the pyridyl $\mathrm{C} 4$ position followed by a borylation/oxidation sequence would serve to introduce the remaining oxygen substituent. ${ }^{37}$ Thus, treatment of $\mathbf{1 6}$ with excess base followed by trimethylborate ( 5 equiv of $\mathrm{BuLi}, 6$ equiv of $\mathrm{B}(\mathrm{OMe})_{3},-78^{\circ} \mathrm{C}, 1 \mathrm{~h}, 88 \%$ ), and oxidative cleavage of the resulting aryl boronate ester provided the $C$-silylated product 17 resulting from both the desired $\mathrm{C} 4$ ' hydroxylation and a competitive reverse Brook rearrangement of the benzylic TIPS ether under the strongly basic conditions. ${ }^{38}$ This unexpected result was confirmed with an X-ray analysis of $\mathbf{1 7}$ (Figure 3). ${ }^{35}$ The use of fewer equivalents of base resulted in the product arising only from silyl migration indicating that the primary site of the deprotonation under these conditions was the benzylic center, and the use of alternative silyl ether protecting groups (TBS and TBDPS) or the free alcohol $\mathbf{1 5}$ itself resulted in lower yields of the diol $\mathbf{1 9}$. The deprotection of $\mathbf{1 7}$ proceeded cleanly and, interestingly, through the $O$-silylated intermediate 18 resulting from an initial Brook rearrangement, to give $19\left(\mathrm{Bu}_{4} \mathrm{NF}, \mathrm{THF}, 25^{\circ} \mathrm{C}, 36 \mathrm{~h}, 96 \%\right)$. Thus, if the desilylation reaction 
was quenched after $30 \mathrm{~min}$ versus $36 \mathrm{~h}$, the intermediate $O$-silyl ether $\mathbf{1 8}$ was isolated in yields as high as $80 \%$, and its resubjection to the reaction conditions for a longer period resulted in clean conversion on to 19. Conversion of $\mathbf{1 9}$ to the heterobenzylic bromide $\mathbf{2 0}$ (1 equiv of $\mathrm{CBr}_{4}, 1$ equiv of $\mathrm{Ph}_{3} \mathrm{P}, \mathrm{CH}_{2} \mathrm{Cl}_{2}, 25^{\circ} \mathrm{C}, 30 \mathrm{~min}, 84 \%$ ) provided a surprisingly stable partner for the Stille cross-coupling given that the parent 2-bromomethyl pyridine is unstable to storage.

We anticipated that a Julia-Kocienski olefination ${ }^{39}$ coupling would allow introduction of the requisite trans C5-C6 alkene while convergently assembling the side chain. Such an approach necessitated the preparation of the vinyl iodide 23 that constitutes the $\mathrm{C} 2-\mathrm{C} 5$ segment. This was accomplished through the reaction of alcohol $\mathbf{2 1}^{40}$ with 1-phenyl-1H-tetrazole-5-thiol (PTSH) under Mitsunobu conditions (DEAD, $\mathrm{Ph}_{3} \mathrm{P}, \mathrm{THF}, 0{ }^{\circ} \mathrm{C}, 30 \mathrm{~min}, 71 \%$ ) to provide thioether 22, which was cleanly oxidized to the sulfone $\mathbf{2 3}$ with $\mathrm{H}_{2} \mathrm{O}_{2}$-ammonium molybdate (EtOH-THF, $25^{\circ} \mathrm{C}, 6 \mathrm{~h}, 89 \%$ ), Scheme 3.41

With this sulfone bearing the vinyl iodide in hand, the stage was set for its coupling with the C6-C13 side chain aldehyde 35, accessible from the known alcohol 27. ${ }^{17}$ Limitations in the reported synthesis of the alcohol 27 (problematic diastereomer separation), ${ }^{17}$ ultimately resulted in our use of a recently disclosed and more effective asymmetric anti-aldol reaction for the preparation of $\mathbf{3 0}$ (Scheme 4$) .42$

Thus, Whiting et al. reported ${ }^{17}$ the preparation of the aldehyde $\mathbf{3 0}$ in their efforts directed at the piericidin A1 side chain utilizing an asymmetric anti-aldol ${ }^{43}$ of the aldehyde 25 and the chiral enolate derived from $\mathbf{2 4}$ providing $\mathbf{2 6}$ ( $84 \%$ ee, 23\% for three steps to 27 ) from which the undesired diastereomers proved difficult to separate. Consequently, we adopted a more recent preparation of aldehyde $\mathbf{3 0}$ disclosed by Nakao 42 utilizing a procedure developed by Heathcock ${ }^{44}$ enlisting 2 equiv of $\mathrm{Bu}_{2} \mathrm{BOTf}$ to promote an anti-selective aldol addition of the Evans optically active $N$-acyl oxazolidinone $\mathbf{2 8}$. As our work progressed, we also briefly examined the conditions recently disclosed by Evans ${ }^{45}$ for promoting such direct anti-aldol additions of the optically active $N$-acyl oxazolidinones. Thus, the reaction of $\mathbf{3 1}$ with $\mathbf{2 5}$ provided $32\left(\mathrm{MgCl}_{2}, \mathrm{TMSCl}, \mathrm{Et}_{3} \mathrm{~N}, \mathrm{EtOAc}, 25{ }^{\circ} \mathrm{C}, 24 \mathrm{~h}, 49 \%\right)$ in good yield and excellent diastereoselectivity. Protection of 32 (TBSCl, imidazole, DMF, $25^{\circ} \mathrm{C}, 16 \mathrm{~h}$ ) followed by reduction with $\mathrm{LiBH}_{4}$ (THF, $\mathrm{MeOH}, 0$ to $25^{\circ} \mathrm{C}, 76 \%$ for two steps) provided an alternative and comparable approach to alcohol 27 which was oxidized to the aldehyde $30 .{ }^{17}$ The aldehyde 30 was converted to alcohol $\mathbf{3 4}$ in two steps as previously disclosed ${ }^{17}$ and oxidized under Swern conditions to give $35\left((\mathrm{COCl})_{2}, \mathrm{DMSO}, \mathrm{Et}_{3} \mathrm{~N},-78^{\circ} \mathrm{C}, 99 \%\right)$, Scheme 5 . The modified Julia coupling between 35 and 23 cleanly provided 36(KHMDS, DME, $-78{ }^{\circ} \mathrm{C}, 18 \mathrm{~h}, 60 \%$ ) with the trans alkene isomer as the only detected product. Lithium-halogen exchange of the vinyl iodide 36 upon treatment with $n$-BuLi, followed by treatment of the vinyllithium with $\mathrm{Bu}_{3} \mathrm{SnCl}$ provided the vinyl stannane $37\left(n-\mathrm{BuLi},-78{ }^{\circ} \mathrm{C}, 20 \mathrm{~min} ; \mathrm{Bu}_{3} \mathrm{SnCl}, 20 \mathrm{~min},-78\right.$ to 25 ${ }^{\circ} \mathrm{C}$ ) for the Stille coupling with $\mathbf{2 0}$.

In initial studies on this final coupling reaction, it was found that only the $\operatorname{Pd}_{2}(\mathrm{dba})_{3} / t-\mathrm{Bu}_{3} \mathrm{P}$ catalyst system employed by Fu and coworkers was able to affect the desired reaction between the bromide 20 with the simplified vinyl stannane $\mathbf{5 0}$ (vide infra). ${ }^{46}$ In these studies, it was found that coupling required elevated temperatures, high catalyst loading, and $\mathrm{LiCl}$ as an additive to achieve good conversions, and when applied to the coupling of $\mathbf{2 0}$ with $\mathbf{3 7}$ provided 38 in superb conversions $\left(\mathrm{Pd}_{2}(\mathrm{dba})_{3}, t-\mathrm{Bu}_{3} \mathrm{P}, \mathrm{LiCl}\right.$, dioxane, $\left.70{ }^{\circ} \mathrm{C}, 18 \mathrm{~h}, 74 \%\right)$ without protection of the pyridyl phenol. Little or no reaction was observed at room temperature, $\left(\mathrm{Ph}_{3} \mathrm{P}\right)_{4} \mathrm{Pd}$ and $(\mathrm{PhCN})_{2} \mathrm{PdCl}_{2}$ failed to support the reaction, $\mathrm{DMF}\left(100{ }^{\circ} \mathrm{C}, 20 \%\right)$ was much less effective as a solvent than dioxane, and the addition of base $\left(\mathrm{NaHCO}_{3}, i-\mathrm{Pr}_{2} \mathrm{NEt}\right)$ did not affect or improve the conversions. A final deprotection of the TBS ether $\mathbf{3 8}\left(\mathrm{Bu}_{4} \mathrm{NF}, \mathrm{THF}, 50\right.$ ${ }^{\circ} \mathrm{C}, 12 \mathrm{~h}, 93 \%$ ) provided piericidin A1 identical in all respects with properties reported for the 
natural product (Scheme 5). However the magnitude of the optical rotation for synthetic $\mathbf{1}$ and that reported for natural $\mathbf{1}\left([\alpha]_{\mathrm{D}} 25+1.8(c 0.1, \mathrm{MeOH})\right.$ for synthetic $\mathbf{1}$ vs $\operatorname{lit}^{47}[\alpha]_{\mathrm{D}}{ }^{25}+1.0(c$ $0.1, \mathrm{MeOH})$ ) was not sufficient for an unambiguous assignment of the absolute configuration. In order to more confidently address this assignment, the conversion of $\mathbf{1}$ to piericidin B1 (2), which exhibits a larger optical rotation, was conducted. ${ }^{48}$ Thus, selective protection of the pyridine hydroxyl of $\mathbf{1}$ as its pivolate ester $39\left(\mathrm{PivCl}, \mathrm{HSO}_{4} \mathrm{NBu}_{4}\right.$, aqueous $5 \mathrm{~N} \mathrm{NaOH}-$ $\mathrm{CH}_{2} \mathrm{Cl}_{2}, 30 \mathrm{~min}, 25^{\circ} \mathrm{C}, 92 \%$ ), followed by $O$-methylation of the remaining secondary alcohol $40\left(\mathrm{NaH}, \mathrm{MeI}, \mathrm{DMF}, 25^{\circ} \mathrm{C}, 1 \mathrm{~h}, 78 \%\right)$, and pivolate hydrolysis of $\mathbf{4 0}\left(t-\mathrm{BuONa}, \mathrm{MeOH}, 60^{\circ}\right.$ $\mathrm{C}, 3 \mathrm{~h}, 88 \%$ ) provided 2 . Synthetic piericidin $\mathrm{B} 1$ proved identical in all respects with properties reported for natural 2 , including its optical rotation $\left([\alpha]_{\mathrm{D}} 25-7.3(c 0.2, \mathrm{MeOH}) \mathrm{vs} \mathrm{lit} 48\right.$ $\left.[\alpha]_{\mathrm{D}} 18-6.5(c 3.2, \mathrm{MeOH})\right)$, thereby confirming the absolute configuration assignment for $\mathbf{1}$ and 2 .

\section{Key Analogues}

Following the completion of the total synthesis of $\mathbf{1}$ and $\mathbf{2}$, our efforts turned to the preparation and evaluation of a series of key analogues. Throughout our studies and the handling of $\mathbf{1 , 2}$, $17,19,20$, and 38, only the 4-hydroxypyridine tautomer, and not the 4-pyridone tautomer, was observed even in protic solvents. Provocatively, this suggests that the ability of $\mathbf{1}$ to bind and inhibit NADH-ubiquinone reductase (Complex I) may result from mimicry of reduced coenzyme Q (hydroquinone) rather than $\mathbf{3}$ itself. Thus, modifications of the $\mathrm{C} 4$ ' hydroxyl could directly address such questions. Similarly, modifications to the side chain of the piericidins would permit the role of its substituents to be more clearly defined.

\section{Key Side Chain Analogues}

Early studies on the piericidins illustrated that simplifications in the side chain, mimicking that found in coenzyme $\mathrm{Q}$, provide derivatives that maintain much of the potency of the natural products. ${ }^{18,19}$ However, all such work was conducted only with an assessment of Complex I inhibition and without regard for comparisons in subsequent cellular functional assays that would more specifically address their potential antitumor activity. The results of prior studies would suggest that removal of $\mathrm{C} 9$ and $\mathrm{C} 10$ substituents and/or alterations of the stereochemistry might not have a significant impact. ${ }^{18,19}$ Consequently, in order to further define the role of the side chain $\mathrm{C} 9$ and $\mathrm{C} 10$ stereocenters, ent-1, the inverted $\mathrm{C} 10$ hydroxy diastereomer $\mathbf{4 3}$, and the $\mathrm{C} 10$ ketone $\mathbf{4 6}$, along with $\mathbf{2}$, were viewed as key structures. The unnatural enantiomer of piericidin $\mathrm{A} 1$, ent $\mathbf{- 1}$ in which both the $\mathrm{C} 10$ and $\mathrm{C} 9$ stereocenters are inverted, was accessed through a sequence identical to that described for the total synthesis of $\mathbf{1}$ enlisting the enantiomer of the oxazolidinone 31. The synthesis of the C10 hydroxy diastereomer $\mathbf{4 3}$, as well as the $\mathrm{C} 10$ ketone $\mathbf{4 6}$, required protection of the $\mathrm{C} 4$ pyridyl phenol after it was established that direct oxidation (Dess-Martin, PCC) of $\mathbf{1}$ itself as well as Mitsunobu inversion of the C10 hydroxy group of $\mathbf{1}$ or $\mathbf{3 9}$ were not straightforward. Thus, Dess-Martin oxidation $\left(\mathrm{CH}_{2} \mathrm{Cl}_{2}, 25\right.$ ${ }^{\circ} \mathrm{C}, 30 \mathrm{~min}, 96 \%$ ) of the pivolate ester 39, enlisted as an intermediate in the total synthesis of piericidin B1, provided the ketone $\mathbf{4 1}$ (Scheme 6). Luche reduction of 41 (4 equiv of $\mathrm{NaBH}_{4}$, 6 equiv of $\mathrm{CeCl}_{3} \cdot 7 \mathrm{H}_{2} \mathrm{O}, \mathrm{EtOH},-78$ to $0{ }^{\circ} \mathrm{C}$ ) afforded a readily separable $1: 1$ mixture of the desired $\mathrm{C} 10$ diastereomer $\mathbf{4 2}(38 \%)$ and regenerated $\mathbf{3 9}(38 \%)$ without competitive conjugate reduction. Hydrolysis of the pivolate ester $\mathbf{4 2}\left(t-\mathrm{BuONa}, \mathrm{MeOH}, 60{ }^{\circ} \mathrm{C}, 3 \mathrm{~h}, 79 \%\right)$ provided $\mathbf{4 3}$, the $\mathrm{C} 10$ diastereomer of piericidin $\mathrm{A} 1$. The corresponding ketone $\mathbf{4 6}$ was not accessible from the pivolate ester $\mathbf{4 1}$ requiring hydrolysis conditions that were too harsh for $\mathbf{4 1}$ to withstand. Consequently, piericidin $\mathrm{A} 1$ was converted to acetate $44\left(\mathrm{AcCl}, \mathrm{HSO}_{4} \mathrm{NBu}_{4}\right.$, aqueous $5 \mathrm{~N} \mathrm{NaOH}-\mathrm{CH}_{2} \mathrm{Cl}_{2}, 25^{\circ} \mathrm{C}, 30 \mathrm{~min}, 93 \%$ ), a key analogue of $\mathbf{1}$ in its own right, which was oxidized to the ketone $\mathbf{4 5}$ (Dess-Martin periodinane, $\mathrm{CH}_{2} \mathrm{Cl}_{2}, 25^{\circ} \mathrm{C}, 30 \mathrm{~min}, 89 \%$ ). Mild hydrolysis of $\mathbf{4 5}$, also an interesting analogue of $\mathbf{1}$, provided the ketone $\mathbf{4 6}\left(\mathrm{NaHCO}_{3}, \mathrm{MeOH}\right.$, 4 days, $71 \%)$. 
Finally, two analogues containing simplified side chains were prepared for comparison. The first, 51, incorporates the farnesyl side chain found in coenzyme Q $(\mathbf{3})$. Thus, the vinyl stannane 48, accessed from the known vinyl iodide $47^{49}\left(n\right.$ - BuLi, $-78^{\circ} \mathrm{C}, 20 \mathrm{~min} ; \mathrm{Bu}_{3} \mathrm{SnCl}, 20 \mathrm{~min}$, -78 to $\left.25^{\circ} \mathrm{C}\right)$ was coupled with 20 using the conditions developed for $\mathbf{1}\left(\mathrm{Pd}_{2}(\mathrm{dba})_{3}, t-\mathrm{Bu}_{3} \mathrm{P}\right.$, $\mathrm{LiCl}$, dioxane, $70{ }^{\circ} \mathrm{C}, 18 \mathrm{~h}$ ) to provide $\mathbf{5 1}(76 \%)$, an analogue first described in the studies of Rapoport (Scheme 7). ${ }^{18}$ In addition, $\mathbf{5 2}$ incorporating a truncated side chain was also prepared. Coupling of the vinyl stannane 50, derived from the known vinyl iodide $49^{50}\left(n-\mathrm{BuLi},-78^{\circ}\right.$ $\mathrm{C}, 20 \mathrm{~min} ; \mathrm{Bu} 3 \mathrm{SnCl}, 20 \mathrm{~min},-78$ to $\left.25^{\circ} \mathrm{C}\right)$ afforded $\mathbf{5 2}\left(\mathrm{Pd}_{2}\left(\mathrm{dba}_{3}, t-\mathrm{Bu} \mathrm{H}_{3} \mathrm{P}, \mathrm{LiCl}\right.\right.$, dioxane, 70 $\left.{ }^{\circ} \mathrm{C}, 18 \mathrm{~h}, 68 \%\right)$ which was deprotected $\left(\mathrm{Bu}_{4} \mathrm{NF}, \mathrm{THF}, 25^{\circ} \mathrm{C}, 8 \mathrm{~h}, 83 \%\right)$ to afford $\mathbf{5 3}$.

\section{Key Pyridyl Analogues}

A key objective of the analogue assessment was to probe the role of the pyridyl C4' hydroxyl group within $\mathbf{1}$. This was addressed both by its selective protection (i.e., $\mathbf{4 4}$ and $\mathbf{4 5}$ ) as well as with the total synthesis of 4'-deshydroxypiericidin A1 (59). Thus, complementing the availability of the labile C4' acetates $\mathbf{4 5}$ and $\mathbf{4 6}$ of piericidin A1 and its C10 ketone, the hydrolytically stable $\mathrm{C} 4$ ' methyl ether $\mathbf{5 4}$ was prepared by selective methylation of piericidin A1 (MeI, $\mathrm{HSO}_{4} \mathrm{NBu}_{4}$, aqueous $5 \mathrm{~N} \mathrm{NaOH}-\mathrm{CH}_{2} \mathrm{Cl}_{2}, 2{ }^{\circ} \mathrm{C}, 2 \mathrm{~h}, 90 \%$ ), Scheme 8. Similarly, C4' phenol methylation of $\mathbf{5 1}$, bearing the farnesyl side chain, was also conducted providing $55\left(\mathrm{MeI}, \mathrm{HSO}_{4} \mathrm{NBu}_{4}\right.$, aqueous $\left.5 \mathrm{~N} \mathrm{NaOH}-\mathrm{CH}_{2} \mathrm{Cl}_{2}, 25^{\circ} \mathrm{C}, 2 \mathrm{~h}, 90 \%\right)$.

More significantly, C4'-deshydroxypiericidin A1 (58) was prepared by total synthesis for examination. The availability of the pyridyl alcohol $\mathbf{1 5}$, its one-step conversion to the Stille cross-coupling substrate 56 ( 1 equiv of $\mathrm{CBr}_{4}, 1$ equiv of $\mathrm{Ph}_{3} \mathrm{P}, \mathrm{CH}_{2} \mathrm{Cl}_{2}, 25^{\circ} \mathrm{C}, 30 \mathrm{~min}, 79 \%$ ), and its convergent coupling with 37 , constituting the fully functionalized piericidin $\mathrm{A} 1$ side chain, provided $57\left(\mathrm{Pd}_{2}(\mathrm{dba})_{3}, t-\mathrm{Bu}_{3} \mathrm{P}, \mathrm{LiCl}\right.$, dioxane, $\left.70{ }^{\circ} \mathrm{C}, 3 \mathrm{~h}, 66 \%\right)$ in two steps from materials available from the total synthesis of $\mathbf{1}$ and $\mathbf{2}$ (Scheme 9). A final silyl ether deprotection of $\mathbf{5 7}$ (HF-pyridine, $25^{\circ} \mathrm{C}, 48 \mathrm{~h}, 54 \%$ ) provided 58. Similarly, the C4'-deshydroxy analogue 59 bearing the simplified farnseyl side chain was prepared by Stille coupling of $\mathbf{5 6}$ with 48 to provide $59\left(\mathrm{Pd}_{2}(\mathrm{dba})_{3}, t-\mathrm{Bu}_{3} \mathrm{P}, \mathrm{LiCl}\right.$, dioxane, $\left.70{ }^{\circ} \mathrm{C}, 3 \mathrm{~h}, 59 \%\right)$ in a single step (Scheme 9). Thus, an attribute of the route to piericidin that emerged from the failure of 6 to productively provide the fully substituted pyridyl core was the generation of $\mathbf{1 5}$ and the post cycloaddition introduction of the $\mathrm{C} 4$ ' hydroxyl group. Its availability, like that of a subsequent pyridyl core (65, Scheme 10), provided ready access to the corresponding C4'deshydroxypiericidin A1 analogues.

Preceeding studies with simplified structures implicated the C5' methyl group as a key pyridyl substituent although studies to probe its role with an intact piericidin structure have not, to our knowledge, been conducted. ${ }^{19}$ Since it represents a key substituent also found on the quinone of coenzyme $\mathrm{Q}$, a pronounced impact of this substituent might well help establish the apparent structural relationship between the piericidin pyridyl core and the coenzyme Q quinone/ hydroquinone subunit. Consequently, the synthetic approach was modified to access this alternatively substituted pyridine core. This entailed conversion of diethyl oxalate to $\beta$-keto ester $60\left(\mathrm{CH}_{2}=\mathrm{CHMgBr},-78{ }^{\circ} \mathrm{C}\right)$ followed by oxime formation to provide $\mathbf{6 1}\left(\mathrm{NH}_{2} \mathrm{OH}-\mathrm{HCl}\right.$, EtOH, $18 \mathrm{~h}, 45 \%$ for 2 steps). ${ }^{33}$ Treatment of the oxime $\mathbf{6 1}$ with methylsulfinyl chloride and $\mathrm{Et}_{3} \mathrm{~N}\left(\mathrm{CH}_{2} \mathrm{Cl}_{2}, 0{ }^{\circ} \mathrm{C}, 20 \mathrm{~min}\right)$ afforded the $N$-sulfonyl-1-azadiene $\mathbf{6 2}$ which smoothly participated in the Diels-Alder reaction with 8 to yield cycloadduct 63 (toluene, $50^{\circ} \mathrm{C}, 18 \mathrm{~h}$, $51 \%$ for 2 steps from $\mathbf{6 1})$. Aromatization upon treatment of $\mathbf{6 3}$ with $\mathrm{BF}_{3} \cdot \mathrm{OEt}_{2}\left(\mathrm{CH}_{2} \mathrm{Cl}_{2}, 0{ }^{\circ} \mathrm{C}\right.$, $1 \mathrm{~h}, 88 \%)$ afforded the ester 64 which was reduced with DIBALH $\left(\mathrm{CH}_{2} \mathrm{Cl}_{2}, 0{ }^{\circ} \mathrm{C}, 1 \mathrm{~h}, 94 \%\right)$ to provide alcohol $\mathbf{6 5}$ that was protected as the TIPS ether $\mathbf{6 6}$ (TIPSCl, imidazole, DMF, $25^{\circ}$ $\mathrm{C}, 18 \mathrm{~h}, 88 \%$ ). Subjection of $\mathbf{6 6}$ to the borylation/oxidation sequence afforded a mixture of the $C$ - and $O$-silylated products 67 and 68 (5 equiv of BuLi, 6 equiv of $\mathrm{B}(\mathrm{OMe})_{3}, 1 \mathrm{~h}, 37 \%(67)$ and $35 \%(\mathbf{6 8})$ ). This mixture of products does not seem to be a result of partial Brook 
rearrangement of 68 to 67 in the course of the basic aqueous work-up as both products are present by TLC prior to work-up. Moreover extended exposure (18 h) to the aqueous work-up conditions does not change the ratio of the products, suggesting the product mixture arises in the course of the reaction. Deprotection of the $\mathbf{6 7}$ and $\mathbf{6 8}$ mixture $\left(\mathrm{Bu}_{4} \mathrm{NF}, \mathrm{THF}, 25^{\circ} \mathrm{C}, 18 \mathrm{~h}\right.$, $69 \%$ ) afforded 70, and its subsequent conversion to bromide 71 ( 1 equiv of $\mathrm{CBr}_{4}, 1$ equiv of $\mathrm{PPh}_{3}, \mathrm{CH}_{2} \mathrm{Cl}_{2}, 76 \%$ ) proceeded cleanly. In order to access the corresponding 4'-deshydroxy-5'desmethyl derivatives, 65 was similarly converted to the bromide $\mathbf{6 9}$ ( 1 equiv of $\mathrm{CBr}_{4}, 1$ equiv of $\mathrm{PPh}_{3}, \mathrm{CH}_{2} \mathrm{Cl}_{2}, 81 \%$ ).

With heterobenzylic bromides 69 and $\mathbf{7 1}$ in hand, we were positioned to access 5'-desmethyl and 4'-deshydroxy-5'-desmethyl analogues bearing the piericidin side chain as well as the simplified farnesyl side chain. As such, Stille coupling of $\mathbf{7 1}$ with $\mathbf{3 7}$ afforded $\mathbf{7 2}\left(\mathrm{Pd}_{2}(\mathrm{dba})_{3}\right.$, $t$ - $\mathrm{Bu}_{3} \mathrm{P}, \mathrm{LiCl}$, dioxane, $70{ }^{\circ} \mathrm{C}, 18 \mathrm{~h}, 62 \%$ ) which was deprotected (HF-pyridine, $25^{\circ} \mathrm{C}, 48 \mathrm{~h}$, $87 \%$ ) to afford 5'-desmethylpiericidin A1 (73). Similarly and without optimization, 4'deshydroxy-5'-desmethylpiericidin A1 (75) was accessed through coupling of $\mathbf{6 9}$ and $\mathbf{3 7}$ $\left(\mathrm{Pd}_{2}(\mathrm{dba})_{3}, t-\mathrm{Bu}_{3} \mathrm{P}, \mathrm{LiCl}\right.$, dioxane, $\left.70{ }^{\circ} \mathrm{C}, 3 \mathrm{~h}, 49 \%\right)$ followed by deprotection to give $\mathbf{7 5}$ (HFpyridine, $25^{\circ} \mathrm{C}, 48 \mathrm{~h}, 73 \%$ ), and the corresponding farnesyl side chain bearing analogues 76 and 77 were accessed through coupling $\mathbf{7 1}$ with $\mathbf{4 8}\left(\mathrm{Pd}_{2}(\mathrm{dba})_{3}, t-\mathrm{Bu} \mathrm{u}_{3} \mathrm{P}, \mathrm{LiCl}\right.$, dioxane, $70{ }^{\circ} \mathrm{C}$, $18 \mathrm{~h}, 58 \%)$ and 69 with $48\left(\mathrm{Pd}_{2}(\mathrm{dba})_{3}, t-\mathrm{Bu} 3 \mathrm{P}, \mathrm{LiCl}\right.$, dioxane, $\left.70{ }^{\circ} \mathrm{C}, 3 \mathrm{~h}, 54 \%\right)$, respectively.

\section{Compound Assessments}

The natural products and the key analogues were examined for inhibition of Complex I as measured against submitochondrial particles 51 as well as for growth inhibition in a functional, cell-based cytotoxic assay enlisiting a mouse leukemia cell line (L1210), Table 1. At the onset, it should be noted that the latter structure-activity relationship (SAR) data need not follow that of the target-based assay of Complex I inhibition because of the additional features such cellbased assays might select for (e.g., cell permeability). Moreover, it is not yet established that the cytotoxic activity of the piericidins is derived from Complex I inhibition and, as such, the data derived from the cell-based assay may reflect other or additional unidentified targets. Consequently, the trends that emerged from the evaluation of compounds in the two assays are discussed separately below and qualified as to their relationship.

As previously disclosed, piericidin $\mathrm{A} 1$ proved to be a potent Complex I inhibitor $\left(\mathbf{1}, \mathrm{IC}_{50}=3.7\right.$ $\mathrm{nM})$ being slightly more potent in our assay than piericidin $\mathrm{B} 1\left(2, \mathrm{IC}_{50}=5.1 \mathrm{nM}\right)$ and rotenone $\left(4, \mathrm{IC}_{50}=5.0 \mathrm{nM}\right)$. Small modifications in the side chain had little impact on this activity. Thus, $O$-methylation of the $\mathrm{C} 10$ alcohol $\left(2\right.$, piericidin $\left.\mathrm{B} 1, \mathrm{IC}_{50}=5.0 \mathrm{nM}\right)$, its conversion to a ketone $\left(\mathbf{4 6}, \mathrm{IC}_{50}=6.3 \mathrm{nM}\right)$, and the inversion of the $\mathrm{C} 10$ alcohol stereochemistry with $\mathbf{4 3}$ $\left(\mathrm{IC}_{50}=8 \mathrm{nM}\right)$ resulted in modest $\leq 2$-fold reductions in potency. More remarkably, entpiericidin $\mathrm{A} 1$ (ent-1, $\mathrm{IC}_{50}=8.8 \mathrm{nM}$ ), where both the $\mathrm{C} 9$ methyl and $\mathrm{C} 10$ hydroxy are inverted, proved to be only 2.5 -fold less potent than the natural product. Consistent with these observations and with past studies, ${ }^{18}$ replacement of the side chain with the simplified farnesyl side chain lacking these substituents and stereocenters provided an analogue $\mathbf{5 1}\left(\mathrm{IC}_{50}=3.8\right.$ $\mathrm{nM}$ ) that was not distinguishable from 1 itself. Nonetheless, the importance of the presence of the side chain is clear with $\mathbf{5 3}\left(\mathrm{IC}_{50}=10,000 \mathrm{nM}\right)$ where the removal of the $\mathrm{C} 5-\mathrm{C} 16$ segment resulted in a $10^{3}-10^{4}$ fold loss in activity. In total, these observations are consistent with piericidin mimicking coenzyme $\mathrm{Q}$ leading to predicable simplifications in the inhibitor structures.

However, as noted below, these simplifications and trends do not similarly track with the relative cytotoxic potencies of the analogues. Rather, the cytotoxic potency of the analogues dropped progressively with the significance of the structural changes in the side chain. Whereas piericidin $\mathrm{B} 1\left(2, \mathrm{IC}_{50}=6 \mathrm{nM}\right)$ was equipotent with piericidin $\mathrm{A} 1\left(1, \mathrm{IC}_{50}=5 \mathrm{nM}\right)$, the $\mathrm{C} 10$ 
alcohol diastereomer $43\left(\mathrm{IC}_{50}=75 \mathrm{nM}\right)$, the $\mathrm{C} 10$ ketone $46\left(\mathrm{IC}_{50}=600 \mathrm{nM}\right)$, and ent-1 $\left(\mathrm{IC}_{50}=700 \mathrm{nM}\right)$ proved to be $15-150$ fold less potent. Similarly, $51\left(\mathrm{IC}_{50}=95 \mathrm{nM}\right)$ bearing the simplified farnesyl side chain was found to be 20 -fold less potent than $\mathbf{1}$, and $\mathbf{5 3}\left(\mathrm{IC}_{50}=\right.$ $6000 \mathrm{nM}$ ), lacking the C5-C16 segment of the side chain, was expectedly 1000-fold less potent. This would suggest that either the cytotoxic activity of the compounds is not derived solely from Complex I inhibition, or that the side chain substituents and their stereochemistry contribute significantly to 1 reaching its biological target in the functional cellular assay. The impact of the pyridyl C4' hydroxyl group proved just as interesting, especially on the inhibition of Complex I and in light of the potential coenzyme Q structural relationship. Whereas its acetylation $\left(\mathbf{4 4}, \mathrm{IC}_{50}=24 \mathrm{nM} ; \mathbf{4 5}, \mathrm{IC}_{50}=26 \mathrm{nM}\right)$ or methylation $\left(\mathbf{5 4}, \mathrm{IC}_{50}=130 \mathrm{nM}\right)$ led to 7 -fold and 35-fold reductions in potency, its removal altogether with 4'-deshydroxypiericidin $\left(\mathbf{5 8}, \mathrm{IC}_{50}=10 \mathrm{nM}\right)$ had a surprisingly modest impact reducing the Complex I inhibition only 3 -fold. In marked contrast, $O$-methylation of the $\mathrm{C} 4$ ' phenol $\left(\mathbf{5 5}, \mathrm{IC}_{50}=750 \mathrm{nM}\right)$ as well as the removal of the $\mathrm{C} 4$ ' phenol $\left(\mathbf{5 9}, \mathrm{IC}_{50}=400 \mathrm{nM}\right)$ in the analogues bearing the simplified farnesyl side chain reduced Complex I inhibition $>100$-fold. These latter studies support the contention that piericidin $\mathrm{A} 1$ mimics the coenzyme $\mathrm{Q}$ hydroquinone and that the $\mathrm{C} 4$ ' hydroxy group is central to its activity, whereas the surprisingly potent inhibition by 4'-deshydroxypiericidin A1 (58) suggests that the natural products side chain substituents may somehow compensate for losses in binding affinity that result from modifications in the pyridyl core.

With a notable exception, this modification or removal of the pyridyl $\mathrm{C} 4$ ' hydroxy group substantially reduced the cytotoxic activity of the compounds. Thus $O$-methylation of the piericidin C4' phenol $\left(\mathbf{5 4}, \mathrm{IC}_{50}=800 \mathrm{nM}\right)$ or its removal $\left(\mathbf{5 8}, \mathrm{IC}_{50}=800 \mathrm{nM}\right)$ resulted in 200fold reductions in cytotoxic activity and the impact of these changes on the simplified analogues $55\left(\mathrm{IC}_{50}=8000 \mathrm{nM}\right)$ and $\mathbf{5 9}\left(\mathrm{IC}_{50}=5000 \mathrm{nM}\right)$ bearing the farnesyl side chain was an even greater 1000-fold loss in activity. The only exceptions to these generalizations were the $\mathrm{C} 4$ ' $O$-acetyl derivatives $44\left(\mathrm{IC}_{50}=3 \mathrm{nM}\right)$ and $45\left(\mathrm{IC}_{50}=90 \mathrm{nM}\right)$. Thus, C4'- $O$-acetyl piericidin A1 (44) was found to be equally potent, or perhaps slightly more potent, than 1 itself. Although surprising on the surface, this most likely is the result of $O$-acetate hydrolysis in the cellular assay releasing the natural product itself. Similarly, $\mathbf{4 5}$ was found to be roughly six-fold more potent than the free phenol $\mathbf{4 6}$, but still nearly 20 -fold less potent than 1 .

The C5' methyl group of piericidin had a similar remarkable impact on the molecules properties. Its removal with 5'-desmethylpiericidin $\mathrm{A} 1\left(\mathbf{7 3}, \mathrm{IC}_{50}=4.0 \mathrm{nM}\right)$ had little or no impact on Complex I inhibition, whereas its removal in the analogue $76\left(\mathrm{IC}_{50}=110 \mathrm{nM}\right)$ bearing the farnesyl side chain reduced Complex I inhibition 30-fold relative to both $\mathbf{5 1}\left(\mathrm{IC}_{50}=3.8 \mathrm{nM}\right)$ or $1\left(\mathrm{IC}_{50}=3.7 \mathrm{nM}\right)$. Just as remarkable, removing both the $\mathrm{C} 4$ ' hydroxyl and $\mathrm{C} 5$ ' methyl groups with $75\left(\mathrm{IC}_{50}=9.0 \mathrm{nM}\right)$ only reduced the Complex I inhibition ca. 2-fold relative to piericidin A1 itself, whereas this double modification in the analogue $\mathbf{7 7}$ bearing the farnesyl side chain resulted in compound that was $>500$-fold less potent than $\mathbf{1}$ or $\mathbf{5 1}$. As such, the surprisingly potent activity of $\mathbf{7 3}$ and especially $\mathbf{7 5}$ suggests that the natural product side chain substituents (vs the farnesyl side chain) somehow compensates for losses in binding affinity that result from modifications in the pyridyl core.

In an interesting contrast, this removal of the pyridyl C5' methyl group led to an ca. $\geq 500$-fold loss in cytotoxic potency. Thus, 5'-desmethylpiericidin A1 $\left(\mathbf{7 3}, \mathrm{IC}_{50}=2,500 \mathrm{nM}\right)$ proved to be 500-fold less active than the natural product. Removing both the $\mathrm{C} 4$ ' hydroxy group as well as the C5' methyl group led to a compound that was even less potent $\left(\mathbf{7 5}, \mathrm{IC}_{50}=4,000 \mathrm{nM}\right)$. Significantly, this removal of the C5' methyl group had an even larger impact on the cytotoxic activity than the critical $\mathrm{C} 4$ ' hydroxy group. Incorporating these structural changes into analogues bearing the farnesyl side chain (76 and 77) led to even further reductions in the cytotoxic activity $\left(\mathrm{IC}_{50}=5,500\right.$ and 20,000 $\mathrm{nM}$, respectively). 
Clear from these comparisons is the observation that the side chain substituents of piericidin A1 may impact Complex I inhibition and do so most productively and significantly when key structural features of the pyridyl core are removed. Similarly, they enhance the cytotoxic activity of the compounds, but their impact seems to be most significant if the pyridyl core of 1 is intact. In contrast, the pyridyl C4' hydroxy group as well as the C5' methyl substituent appear more central to the molecules properties since their modification or removal leads to reductions in Complex I inhibition and even more significant reductions in the cytotoxic activity where the intact pyridyl core appears most essential. The exception to this generalization is the unusually potent Complex I inhibition by $\mathbf{5 8 , 7 3}$, and $\mathbf{7 5}$ where the piericidin A1 side chain (but not farnesyl) appears to compensate for their removal (Figure 4). Significantly, the series of analogues bearing the farnesyl side chain exhibit trends consistent with expectations of a simple coenzyme Q mimic where both the $\mathrm{C} 4$ ' hydroxyl group and the C5' methyl group each increase either the Complex I inhibition or L1210 cytotoxicity approximately 30-100 fold with the former target-based assay (Complex I) assay exhibiting $\mathrm{IC}_{50}$ 's approximately 10-fold lower than the cell-based (L1210) assay. In marked contrast, the series bearing the piericidin A1 side chain exhibited much smaller 1-2.5 fold losses in Complex I activity with removal of either the $\mathrm{C} 4$ ' hydroxyl or C5' methyl group, while experiencing even greater 200-500 losses in cytotoxic activity in the cellular assay. Even so, this latter series remained roughly 10 -fold more potent (2-20 fold) than the farnesyl series in the cellular assay (L1210) and was typically much more potent (1-200 fold) against Complex I itself. Whether the lack of direct correlation between the two series in the two assays reflects the molecules ability to access Complex I in the cellular assay, the more subtle distinctions between multiple binding sites on Complex I and their biological consequences, or even the intervention of additional biological targets, remain to be established.

\section{Conclusion}

An effective and convergent total synthesis of piericidin A1 and B1 was developed which features a facile $N$-sulfonyl-1-azadiene inverse electron demand Diels-Alder conducted at 50 ${ }^{\circ} \mathrm{C}$ to access the highly functionalized pyridyl core. The side chain was prepared enlisting an asymmetric anti-aldol reaction to install the $\mathrm{C} 9$ and $\mathrm{C} 10$ absolute stereochemistry, and a transselective Julia-Kocienski C5-C6 olefination to convergently assemble the side chain. A surprisingly effective and strategic late stage Stille cross-coupling reaction of the pyridyl core (a heterobenzylic bromide) with the fully functionalized side chain was used to complete the synthesis. Not only did this serve as the first disclosed total synthesis ${ }^{14}$ of a member of this natural product class permitting an unambiguous assignment of the unresolved absolute stereochemistry, but it did so by an approach that permitted access to structural analogues in which either half of the molecule could be divergently altered at a late stage.

Thus, the studies were extended to include total syntheses of ent-piericidin A1 in which both the C9 and C10 stereocenters were inverted, 4'-deshydroxypiericidin A1 (58) and 5'desmethylpiericidin (73) each lacking a key substituent of the putative quinone mimic, 4'deshydroxy-5'-desmethylpiericidin A1 (75), and the simplified analogues 51, 59, 76, and 77 bearing an unfunctionalized farnesyl side chain linked to either the authentic, 4'deshydroxypyridyl, 5'-desmethylpyridyl, or 4'-deshydroxy-5'-desmethylpyridyl core. The evaluation of these key analogues, along with those derived from further functionalization of the analogues and $\mathbf{1}$, permitted a scan of the key structural features providing new insights into the role of substituents found on both the pyridyl core as well as the side chain.

\section{Supplementary Material}

Refer to Web version on PubMed Central for supplementary material. 


\section{Acknowledgement}

We gratefully acknowledge the financial support of the National Institutes of Health (D.L.B. CA 42056 and T.Y. GM 33712) and the Skaggs Institute for Chemical Biology. MJS is a Skaggs Fellow. FAR acknowledges the American Cancer Society for a postdoctoral fellowship.

\section{References}

1. Takahashi N, Suzuki A, Tamura S. J. Am. Chem. Soc 1965;87:2066. [PubMed: 14290282]

2. Nelson, DL.; Cox, MM. Lenhinger Principles of Biochemistry. Worth; New York: 2000. Chapter 19

3. Esposti MD. Biochim. Biophys. Acta 1998;1364:222. [PubMed: 9593904]

4. Yoshida S, Yoneyama K, Shiraishi S, Watanbe A, Takahashi N. Agric. Biol. Chem 1977;41:849.

5. Kimura K, Takahashi H, Miyata N, Yoshihama M, Uramoto M. J. Antibiot 1996;49:697. [PubMed: 8784434]

6. Matsumoto M, Mogi K, Nagaoka K, Ishizeki S, Kawahara R, Nakashima T. J. Antibiot 1987;40:149. [PubMed: 3570963]

7. Ahn SC, Kim BY, Oh WK, Kang DO, Heo GY, Kim MS, Lee MS, Ahn JS. J. Antibiot 2002;55:1013. [PubMed: 12546423]

8. Kitaura, N.; Shirata, K.; Niwano, M.; Mimura, M.; Takahara, Y. Chem. Abstr Japanese Patent 05339156 A2, 1993. 1994. p. 208590

9. Udeani GO, Gerhauser C, Thomas CF, Moon RC, Kosmeder JK, Kinghorn AD, Moriarty RM, Pezzuto JM. Cancer Res 1997;57:3424. [PubMed: 9270008] and references cited therein

10. Fang N, Casida JE. Proc. Natl. Acad. Sci. USA 1998;95:3380. [PubMed: 9520374]

11. Li N, Ragheb K, Lawler G, Sturgis J, Rajwa B, Melendez JA, Robinson JP. J. Biol. Chem 2003;278:8516. [PubMed: 12496265]

12. Kushnareva Y, Murphy AN, Andreyev A. Biochem. J 2002;368:545. [PubMed: 12180906]

13. Sherer TB, Betarbet R, Testa CM, Seo BB, Richardson JR, Kim JH, Miller GW, Yagi T, MatsunoYagi A, Greenamyre JT. J. Neurosci 2003;34:10756. [PubMed: 14645467]

14. Schnermann MJ, Boger DL. J. Am. Chem. Soc 2005;127:15704. [PubMed: 16277503]

15. Keaton KA, Phillips AJ. J. Am. Chem. Soc 2006;128:408. [PubMed: 16402817]

16. (a) Ono M, Yoshida N, Kokubu Y, Sato E, Akita H. Chem. Pharm. Bull 1997;45:1428. (b) Ono M, Yoshida N, Akita H. Chem. Pharm. Bull 1997;45:1745.

17. Cox CM, Whiting DA. J. Chem. Soc. Perkin Trans 1991;1:1901.

18. (a) Schmidtchen FP, Rapoport H. J. Am. Chem. Soc 1977;99:7014. [PubMed: 561812] (b) Gutman M, Klaitchko S. FEBS Lett 1976;67:348. [PubMed: 986952]

19. Yoshida S, Takahashi N. Heterocycles 1978;10:425.

20. Chung KH, Cho KY, Asami. Y; Takahashi N, Yoshida S. Z. Naturforsch 1989;44c:609.

21. Takahashi N, Suzuki A, Kimura Y, Miyamoto S, Tamura S. Tetrahedron Lett 1967;8:1961. [PubMed: 6043699]

22. Yoshida S, Shiraishi S, Fujita K, Takahashi N. Tetrahedron Lett 1975;16:1863.

23. Jansen R, Hofle G. Tetrahedron Lett 1983;24:5485.

24. (a) Boger DL, Corbett WL, Wiggins JM. J. Org. Chem 1990;55:2999. (b) Boger DL, Corbett WL, Curran TT, Kasper AM. J. Am. Chem. Soc 1991;113:1713. (c) Boger DL, Kasper AM. J. Am. Chem. Soc 1989;111:1517. (d) Boger DL, Curran TT. J. Org. Chem 1990;55:5439. (e) Clark RC, Pfeiffer SS, Boger DL. J. Am. Chem. Soc 2006;128:2587. [PubMed: 16492042] (f) Boger DL. etraThedron 1983;39:2869.Reviews:Boger DL. Chem. Rev 1986;86:781.Boger DL. Chemtracts: Org. Chem 1996;9:149.

25. Scheeren JW, Staps RJFM, Nivard RJF. Rec. Trav. Chim 1973;92:11.

26. (a) Boger DL, Cassidy KC, Nakahara S. J. Am. Chem. Soc 1993;115:10733. (b) Boger DL, Hüter O, Mbiya K, Zhang M. J. Am. Chem. Soc 1995;117:11839. (c) Boger DL, Hong J. J. Am. Chem. Soc 1998;120:1218. (d) Boger DL, Blagg BSJ. Tetrahedron 2002;58:6343.

27. Boger DL, Brotherton CE. J. Org. Chem 1984;49:4050. 
28. Friedrich T, Van Heek P, Leif H, Ohnishi T, Forche E, Kunze B, Jansen R, Trowitzsch-Kienast W, Hofle G, Reichenbach H, Weiss H. Eur. J. Biochem 1994;219:691. [PubMed: 8307034]

29. Okun JG, Lummen P, Brandt U. J. Biol. Chem 1999;274:2625. [PubMed: 9915790]

30. Ramsay RR, Krueger MJ, Youngster SK, Gluck MR, Casida JE, Singer TP. J Neurochem 1991;56:1184. [PubMed: 2002336]

31. Lummen P. Biochim. Biophys. Acta 1998;1364:287. [PubMed: 9593947]

32. Synthesis described in supporting information.

33. Rambaud M, Bakasse M, Duguay G, Villieras J. Synthesis 1988:564.

34. Brown C, Hudson RF, Record KAF. J. Chem. Soc., Perkin Trans 1978;2:822.

35. The coordinates of the X-ray structures of $\mathbf{1 3}$ (CCDC 600039) and $\mathbf{1 7}$ (CCDC 600040) have been deposited with the Cambridge Crystallographic Data Centre.

36. Boger DL, Nakahara S. J. Org. Chem 1991;56:880.

37. Trecourt F, Mallet M, Mongin F, Queguiner G. J. Org. Chem 1994;59:6173.

38. Wright A, West R. J. Am. Chem. Soc 1974;96:3214.

39. Blakemore PR, Cole WJ, Kocienski PJ, Morley A. Synlett 1998:26.

40. Ndibwani A, Lamothe S, Guay D, Plante R, Soucy P, Goldstein S, Deslongchamps P. Can. J. Chem 1993;71:695.

41. Ahmed A, Hoegenauer EK, Enev VS, Hanbauer M, Kaehlig H, Ohler E, Mulzer J. J. Org. Chem 2003;68:3026. [PubMed: 12688769]

42. Nakao Y, Yoshida WY, Takada Y, Kimura J, Yang L, Mooberry SL, Scheuer PJ. J. Nat. Prod 2004;67:1332. [PubMed: 15332851]

43. Gennari C, Bernardi A, Colombo L, Scolastico C. J. Am. Chem. Soc 1985;107:5812.

44. Danda H, Hansen MM, Heathcock CH. J. Org. Chem 1990;55:173.

45. Evans DA, Tedrow JS, Shaw JT, Downey CW. J. Am. Chem. Soc 2002;124:392. [PubMed: 11792206]

46. Littke AF, Schwarz L, Fu GC. J. Am. Chem. Soc 2002;124:6343. [PubMed: 12033863]

47. Urakawa A, Sasaki T, Yoshida K, Otani T, Lei Y, Yun W. J. Antibiot 1996;49:1052. [PubMed: 8968401]

48. Takahashi N, Suzuki A, Kimura Y, Miyamoto S, Tamura S, Mitsui T, Fukami J. Agric. Biol. Chem 1968;32:1115.

49. Svatos A, Urbanova K, Valterova I. Collect. Czech. Chem. Commun 2002;67:83.

50. Andresen G, Eriksen AB, Dalhus B, Gunderson LL, Rise F. J. Chem. Soc., Perkin Trans 2001;1:1662.

51. Matsuno-Yagi A, Hatefi Y. J. Biol. Chem 1985;260:14424. 

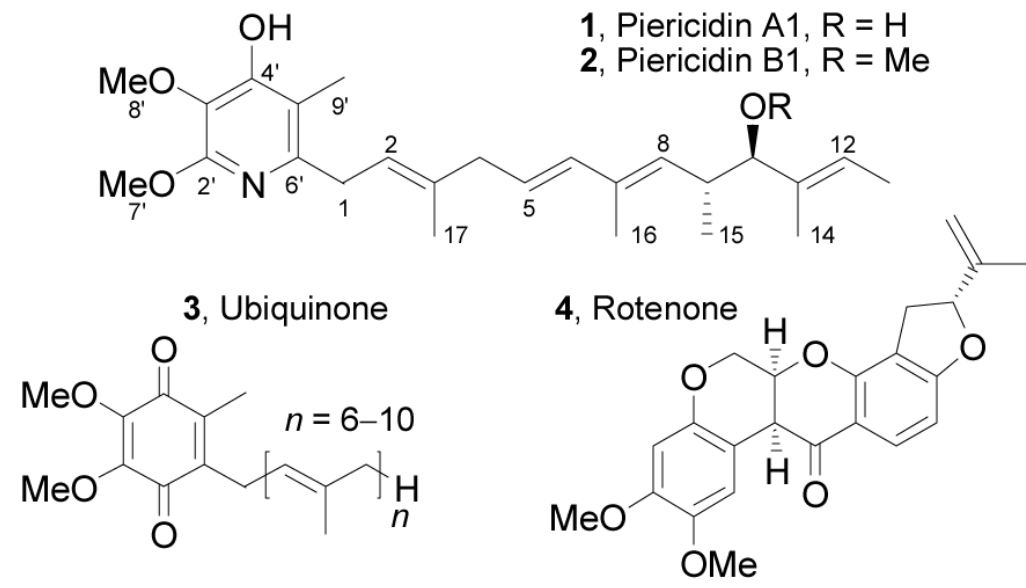

Figure 1.

Structure of Piericidin A1 and B1 


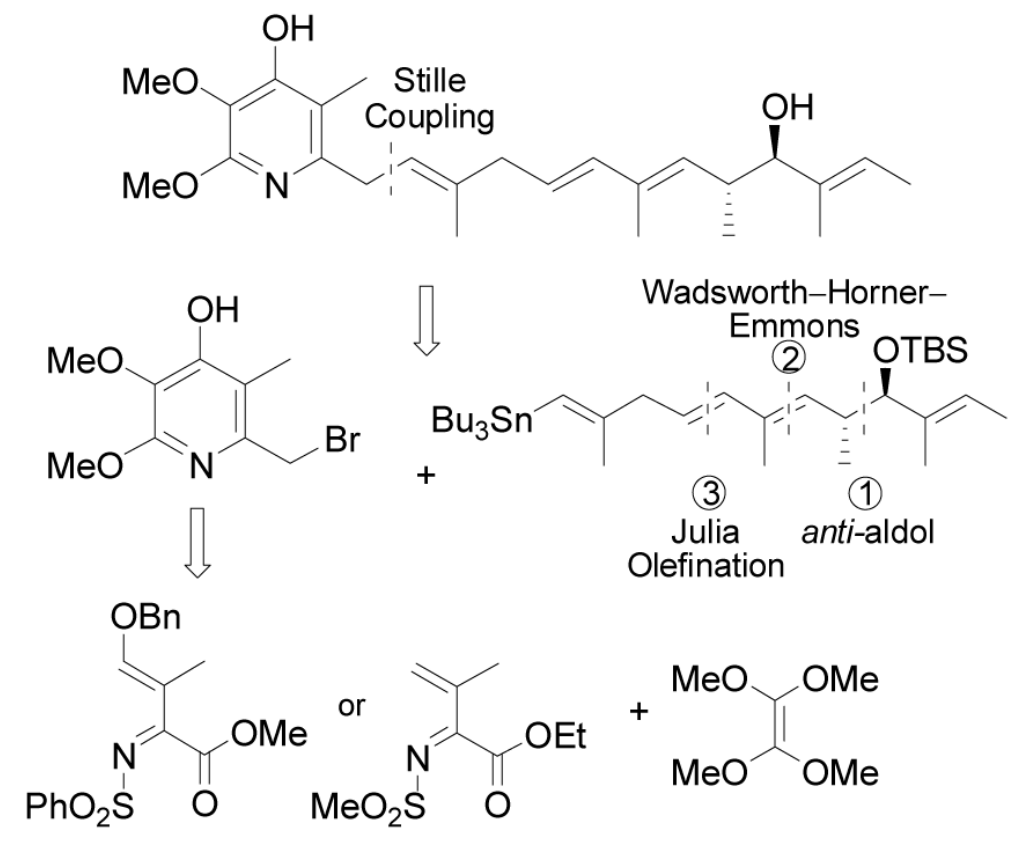

Figure 2.

Retrosynthetic Analysis 

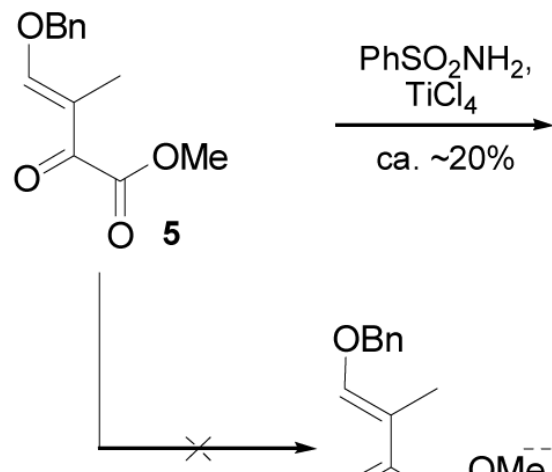

$\mathrm{OBn}$<smiles>C=C(COC#CCOC(C)=O)C(C)=CC</smiles>
$\mathrm{PhO}_{2} \mathrm{~S} \quad \mathrm{O}_{6}$

Scheme 1. 

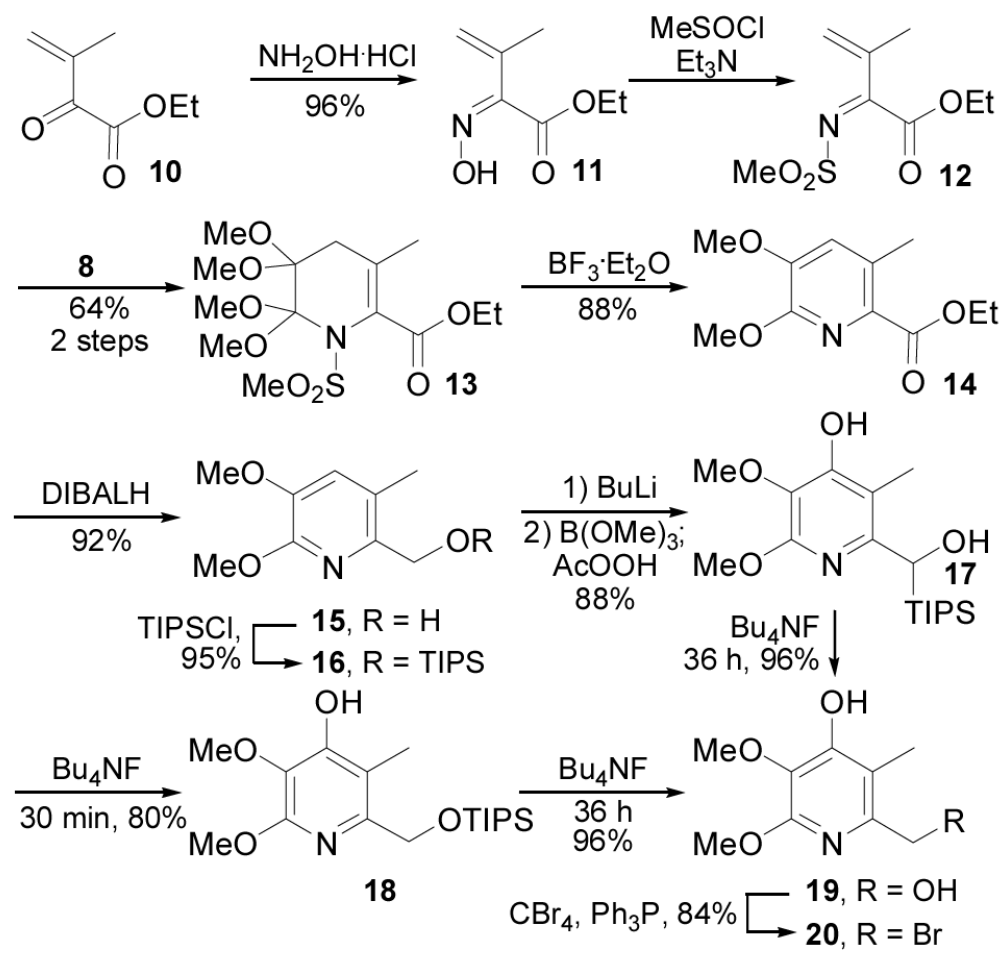

Scheme 2. 

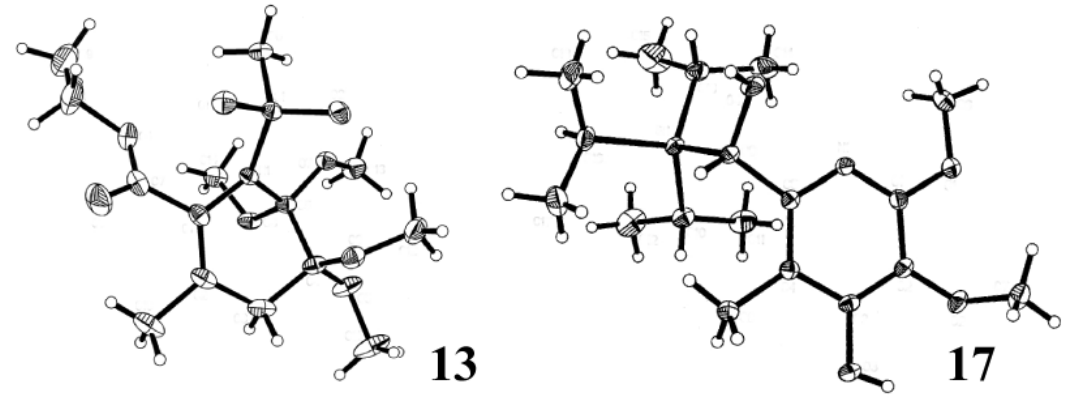

Figure 3.

X-ray crystal structures of $\mathbf{1 3}$ and $\mathbf{1 7}$ 


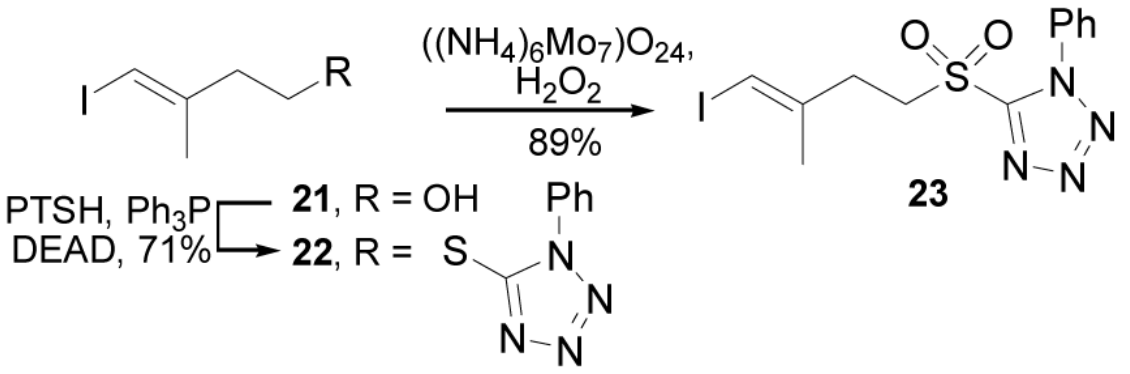

Scheme 3. 


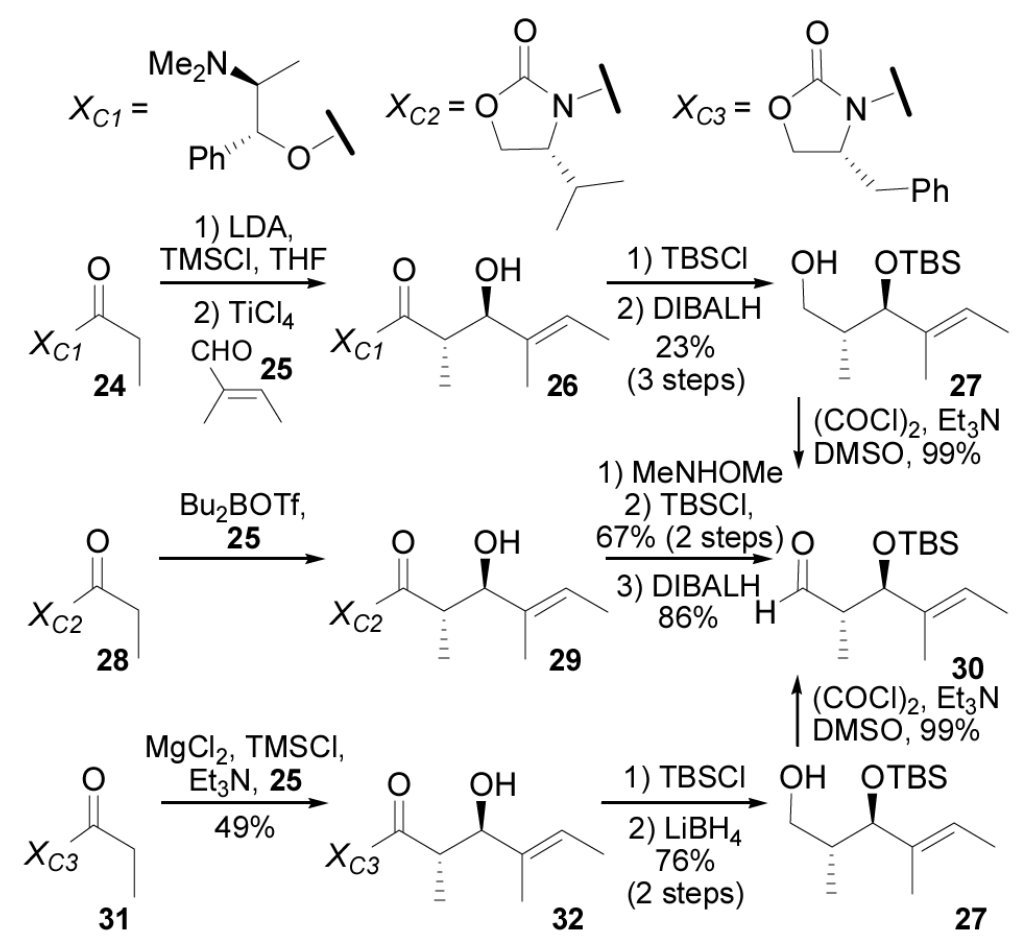

Scheme 4. 
<smiles>CC=C(C)[C@@H]([OH2+])[C@@H](C)C=O</smiles><smiles>CCOC(=O)PC(C)C(=O)OCC</smiles><smiles>[R]C(C)=C[C@@H](C)[C@H]([OH2+])C(=C)C</smiles>

30

DIBALH, $72 \%$ for 2 steps

33, $\mathrm{R}=\mathrm{CO}_{2} \mathrm{Et}$ $(\mathrm{COCl})_{2}, \mathrm{DMSO}, \mathrm{Et}_{3} \mathrm{~N}, 99 \%$

34, $\mathrm{R}=\mathrm{CH}_{2} \mathrm{OH}$

$35, \mathrm{R}=\mathrm{CHO}$

23, KHMDS

$60 \%$

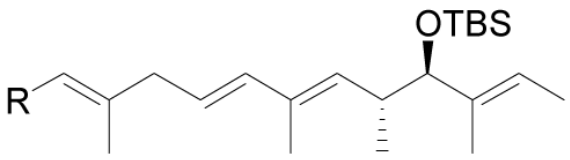

20

$\mathrm{Pd}_{2}(\mathrm{dba})_{3}$, $\underset{7 \mathrm{Bu}_{3} \mathrm{P}, \mathrm{LiCl}}{\longrightarrow}$

$74 \%$

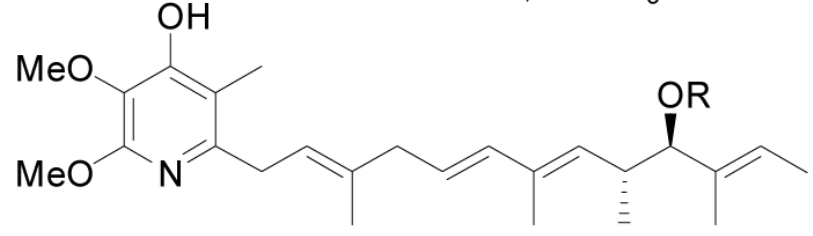

$36, \mathrm{R}=1$

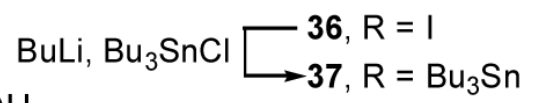



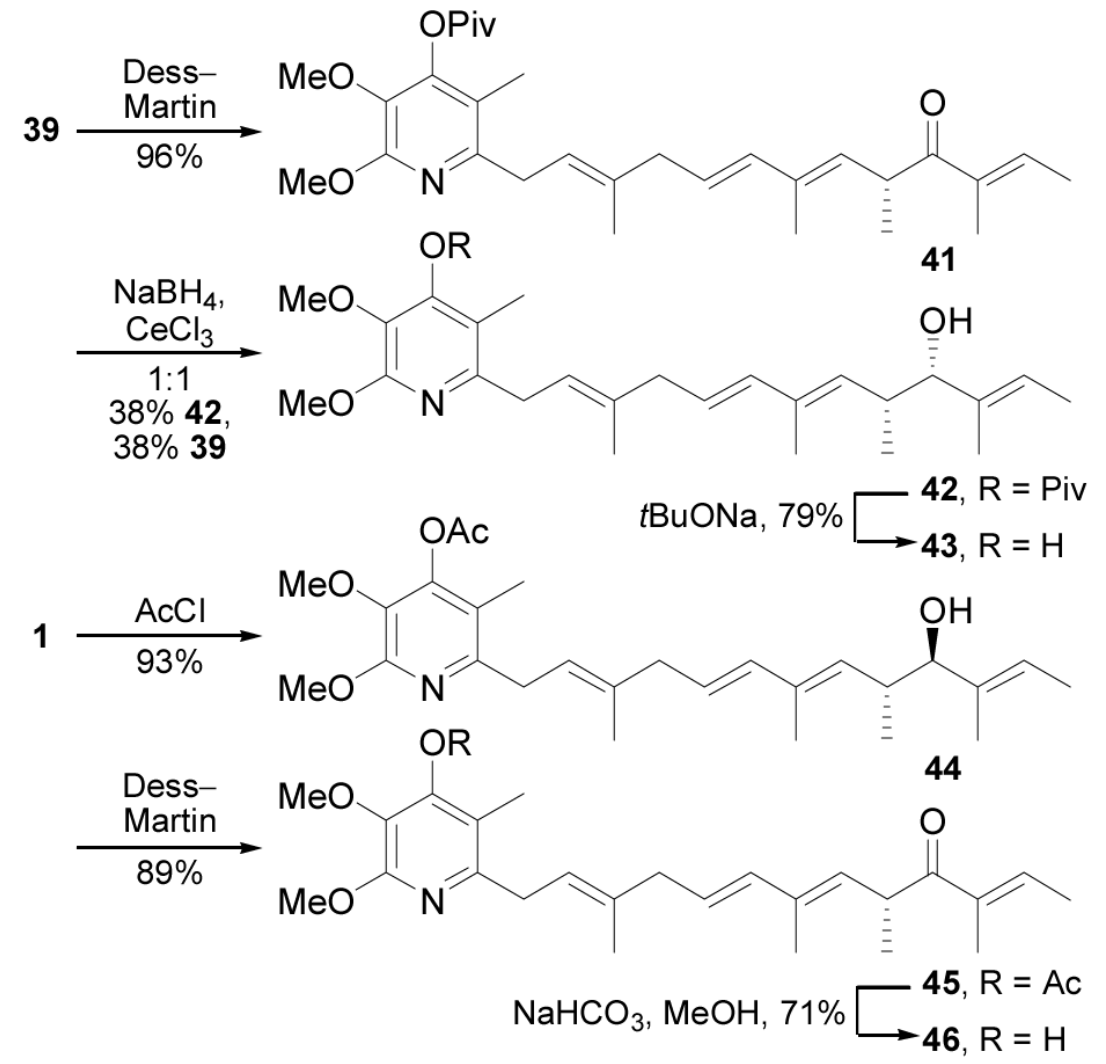

Scheme 6.

Synthesis of Analogues 43, 44, 45 and 46 

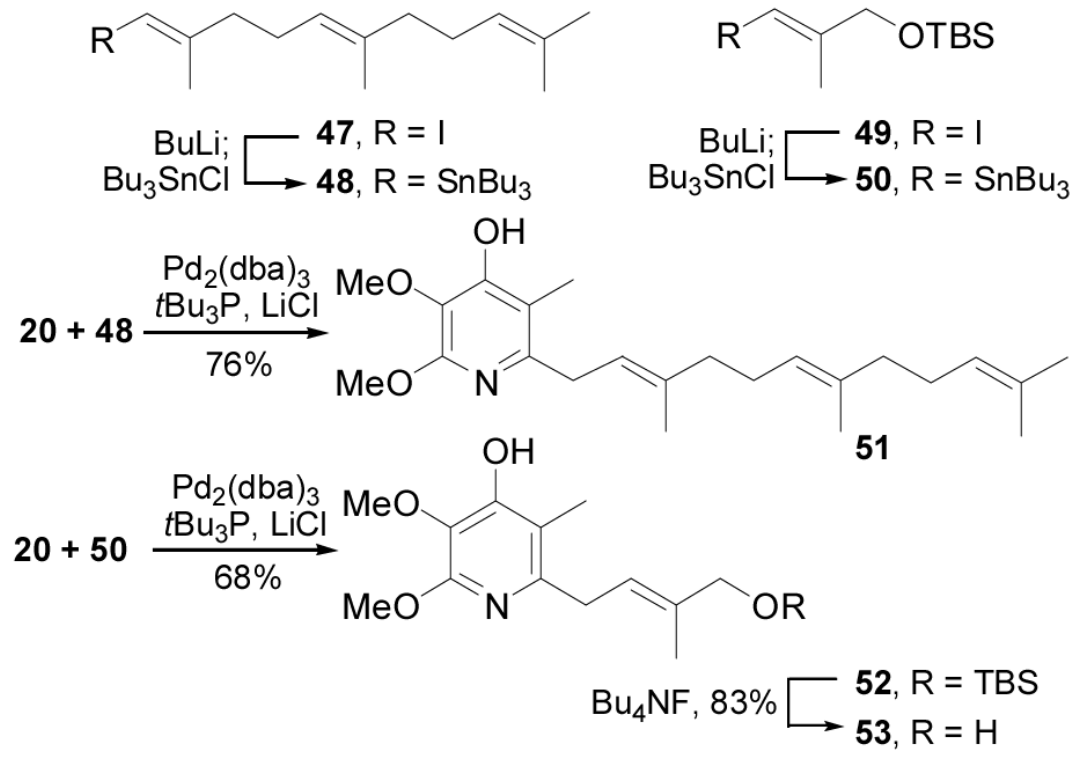

Scheme 7.

Synthesis of Analogues 51 and $\mathbf{5 3}$ 


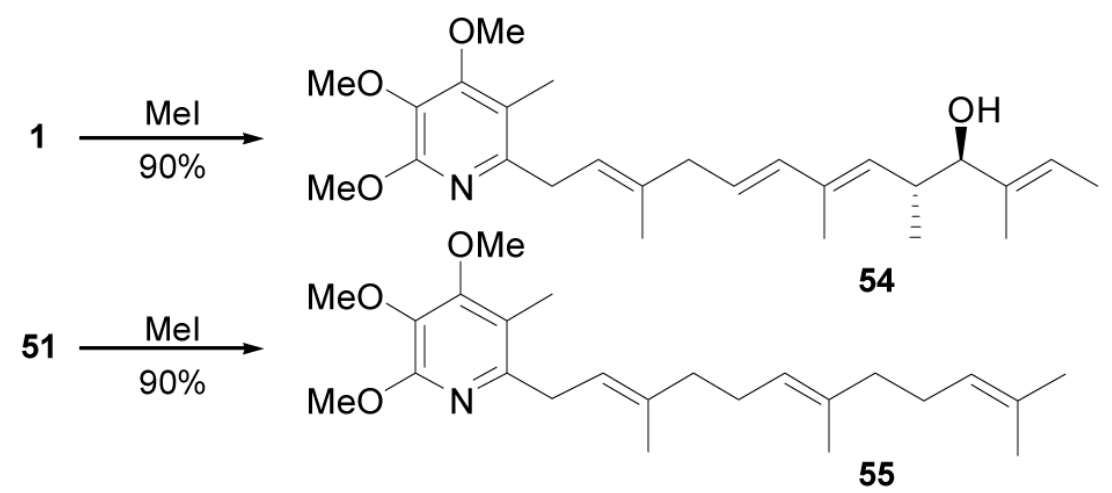

Scheme 8.

Synthesis of Analogues 54 and 55 

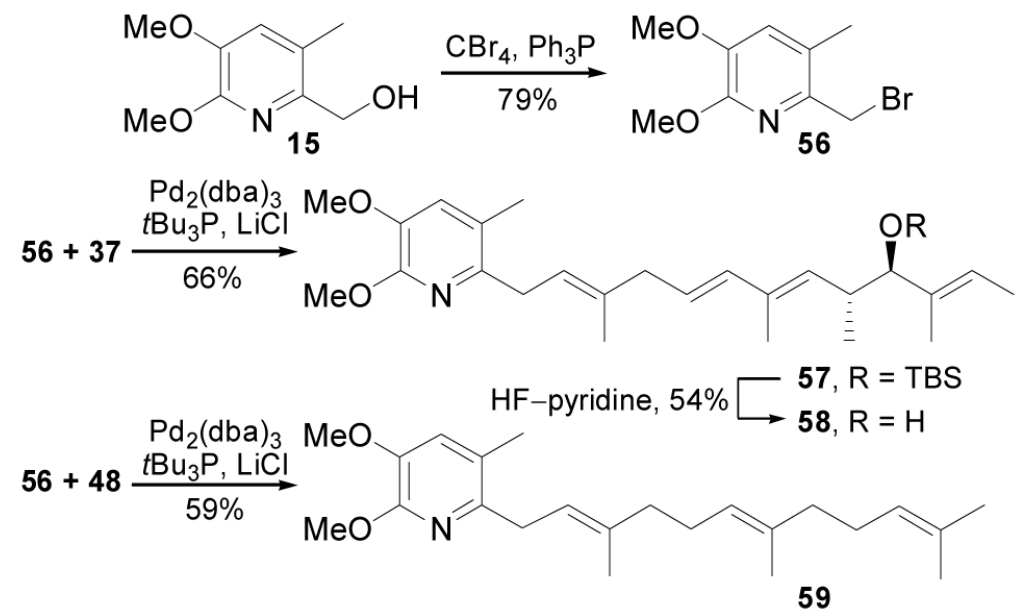

Scheme 9.

Synthesis of Analogues $\mathbf{5 7}$ and $\mathbf{5 9}$ 


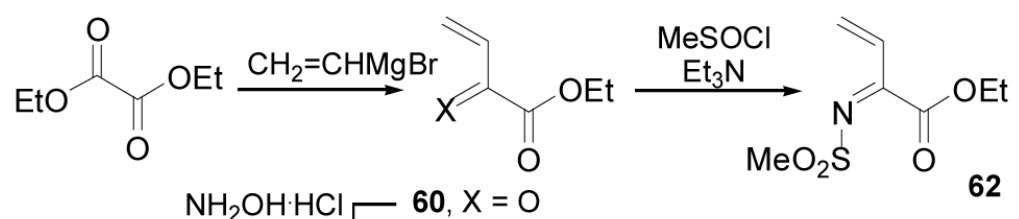
$45 \%$ for 2 steps $\longrightarrow 61, X=\mathrm{NOH}$
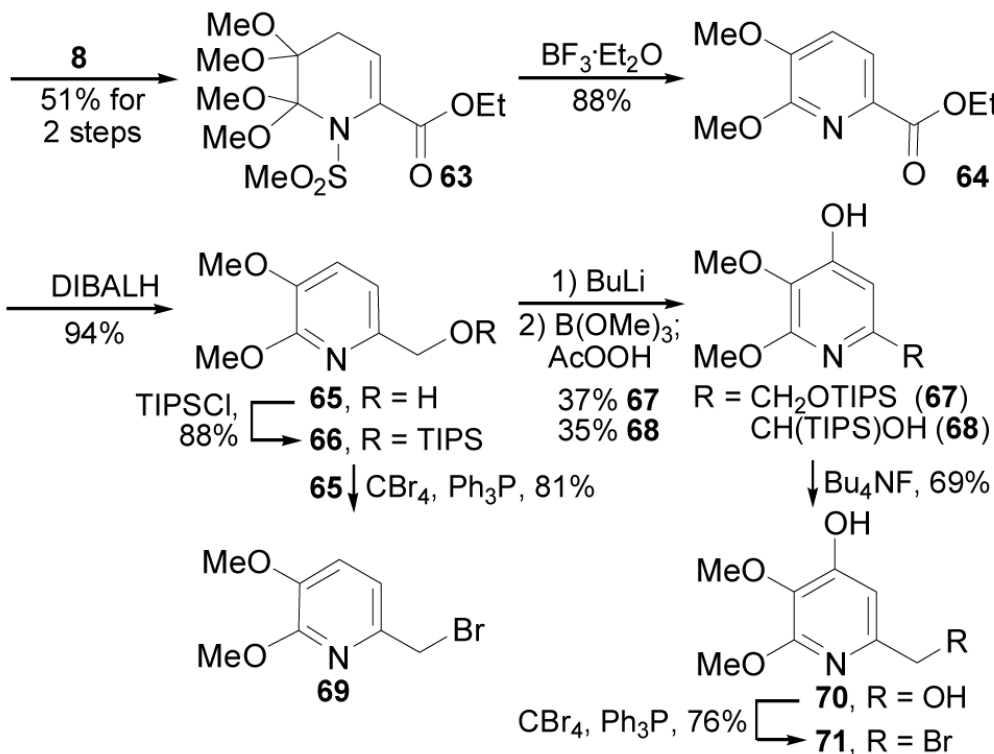

Scheme 10. 
<smiles></smiles><smiles>CCOC(=O)c1ccc(OC)c(OC)n1</smiles>

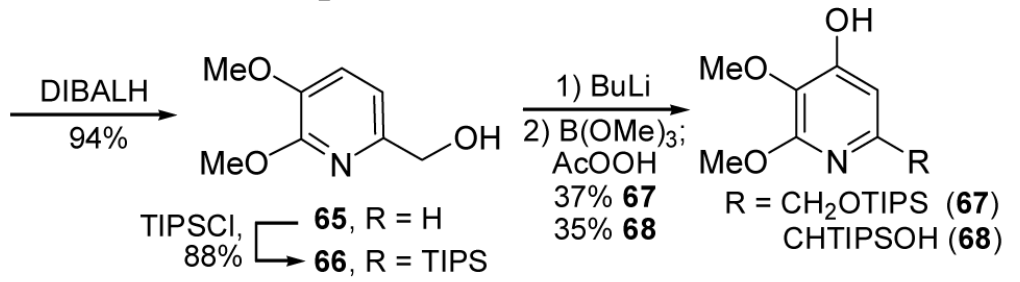

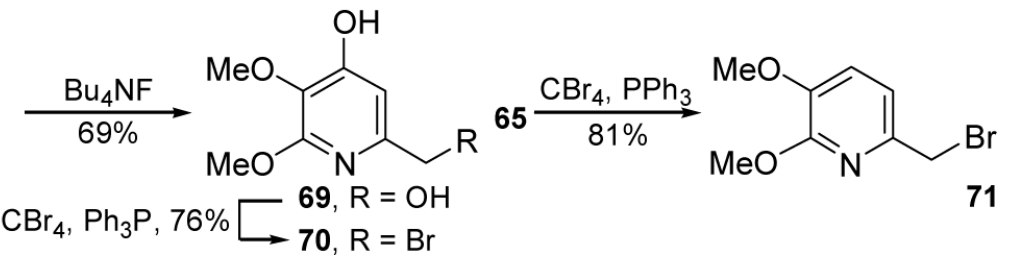

Scheme 11.

Synthesis of Analogues 73, 75, 76, and 77 


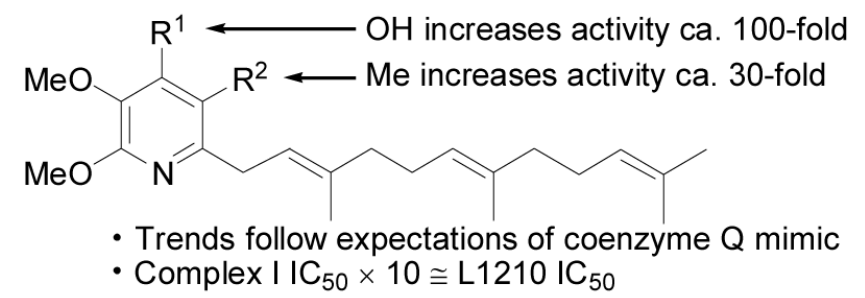

\begin{tabular}{ccccc}
\hline Compd. & $\mathrm{R}^{\mathrm{I}}$ & $\mathrm{R}^{2}$ & $\begin{array}{c}\text { Complex I } \\
\mathrm{IC}_{50}, \mathrm{nM}\end{array}$ & $\begin{array}{c}\mathrm{L} 1210 \\
\mathrm{IC}_{50}, \mathrm{nM}\end{array}$ \\
\hline $\mathbf{5 1}$ & $\mathrm{OH}$ & $\mathrm{CH}_{3}$ & 3.8 & 95 \\
$\mathbf{5 5}$ & $\mathrm{OCH}_{3}$ & $\mathrm{CH}_{3}$ & 750 & 8,000 \\
$\mathbf{5 9}$ & $\mathrm{H}$ & $\mathrm{CH}_{3}$ & 400 & 5,000 \\
$\mathbf{7 6}$ & $\mathrm{OH}$ & $\mathrm{H}$ & 110 & 5,500 \\
$\mathbf{7 7}$ & $\mathrm{H}$ & $\mathrm{H}$ & 2,200 & 20,000 \\
\hline
\end{tabular}

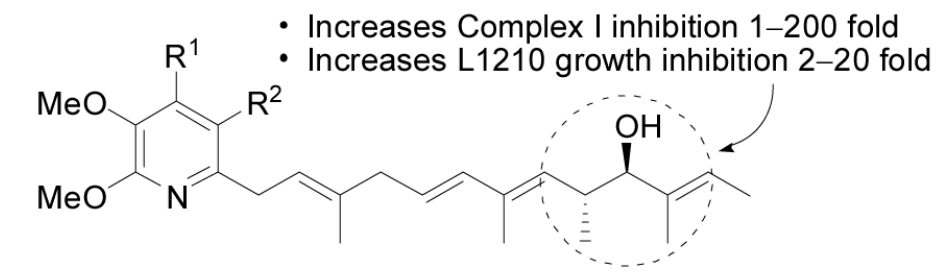

\begin{tabular}{ccccc}
\hline Compd. & $\mathrm{R}^{\mathrm{I}}$ & $\mathrm{R}^{2}$ & $\begin{array}{c}\text { Complex I } \\
\mathrm{IC}_{50}, \mathrm{nM}\end{array}$ & $\begin{array}{c}\mathrm{L} 1210 \\
\mathrm{IC}_{50}, \mathrm{nM}\end{array}$ \\
\hline $\mathbf{1}$ & $\mathrm{OH}$ & $\mathrm{CH}_{3}$ & 3.7 & 5 \\
$\mathbf{5 4}$ & $\mathrm{OCH}_{3}$ & $\mathrm{CH}_{3}$ & 130 & 800 \\
$\mathbf{5 8}$ & $\mathrm{H}$ & $\mathrm{CH}_{3}$ & 10 & 800 \\
$\mathbf{7 3}$ & $\mathrm{OH}$ & $\mathrm{H}$ & 4.0 & 2,500 \\
$\mathbf{7 5}$ & $\mathrm{H}$ & $\mathrm{H}$ & 9.0 & 4,000 \\
\hline
\end{tabular}

Figure 4.

Key Comparisons 
Table 1

Compound Assessments

\begin{tabular}{|c|c|c|}
\hline Compd. & $\begin{array}{c}\text { Mitochondrial } \\
\text { Complex I Inhibition } \\
\text { IC }_{50}(\mathrm{nM})^{a}\end{array}$ & $\begin{array}{c}\mathbf{L 1 2 1 0} \\
\mathrm{IC}_{50}(\mathrm{nM})\end{array}$ \\
\hline $\begin{array}{c}1 \\
\text { ent-1 } \\
\mathbf{2} \\
\mathbf{4} \\
\mathbf{4 3} \\
\mathbf{4 4} \\
\mathbf{4 5} \\
\mathbf{4 6} \\
\mathbf{5 1} \\
\mathbf{5 3} \\
\mathbf{5 4} \\
\mathbf{5 5} \\
\mathbf{5 8} \\
\mathbf{5 9} \\
\mathbf{7 3} \\
\mathbf{7 5} \\
\mathbf{7 6} \\
\mathbf{7 7}\end{array}$ & $\begin{array}{c}3.7 \\
8.8 \\
5.1 \\
5.0 \\
8 \\
24 \\
26 \\
6.3 \\
3.8 \\
10,000 \\
130 \\
750 \\
10 \\
400 \\
4.0 \\
9.0 \\
110 \\
2,200\end{array}$ & $\begin{array}{c}5 \\
700 \\
6 \\
20 \\
75 \\
3 \\
90 \\
600 \\
95 \\
6,000 \\
800 \\
8,000 \\
800 \\
5,000 \\
2,500 \\
4,000 \\
5,500 \\
20,000\end{array}$ \\
\hline
\end{tabular}

${ }^{a}$ Tests performed on bovine submitochondrial particles (SMP).

Concentrations required for half-maximal inhibition, average of 1-2 determinations.

${ }^{b}$ L1210 Cytotoxic activity, average of $1-2$ determinations performed in triplicate. 